\title{
EMPIRE OF SIGNALS: TECHNO-ECOLOGY WITHOUT NATURE IN JAPAN
}

\begin{abstract}
Along with the development of technology undermining the traditional notion of humanity in Judeo-Christianity, a variety of debates on beyond-human phenomena have emerged since the late $20^{\text {th }}$ century. However, without waiting for these debates, outside of the West, similar phenomena have occurred even before the late $20^{\text {th }}$ century. This paper will explore the non-representational forces of human-technology relations in Japan, focusing on the transition of the technological environment from the 1960s to the 1990s. An affective continuum between humans and natural or artificial things, including modern technology in the 1960s, was formed through material interfaces. However, in the 1990s, when electronic technology began to be used to control sensory signals in detail, the equilibrium of representational and non-representational forces became unstable. The paper illustrates an alternate type of humanity-centered limitation which would help to relativize the dominant Western context.
\end{abstract}

Keywords: sign and signal, non-representational theory, Japan, Roland Barthes, Gilbert Simondon

\section{Introduction}

In the realm of media and technology studies, the interest in the non-representational ${ }^{1}$ or the non-human ${ }^{2}$ has recently emerged in concert with new materialism as interdisciplinary fields, ${ }^{3}$ the ontological turn movement ${ }^{4}$ including the actor-network theory in anthropology as well as science and technology studies (STS), ${ }^{5}$ speculative realism

\footnotetext{
N. Thrift, Non-Representational Theory: Space, Politics, Affect, London: Routledge, 2007.

R. Grusin (ed.), The Nonhuman Turn, Minneapolis, MN: University of Minnesota Press, 2015.

D.H. Coole, S. Frost (eds.), New Materialisms: Ontology, Agency, and Politics, Durham, NC: Duke University Press, 2010.

4 M. Holbraad, M.A. Pedersen, The Ontological Turn: An Anthropological Exposition, Cambridge: Cambridge University Press, 2017.

5 B. Latour, Reassembling the Social: An Introduction to Actor-Network-Theory, Oxford: Oxford University Press, 2007.
} 
or object-oriented ontology in philosophy, ${ }^{6}$ gender studies, ${ }^{7}$ animal studies, ${ }^{8}$ and affect theory. ${ }^{9}$ The concepts of media and technology have been dehumanized in media archaeology, ${ }^{10}$ media ecology, ${ }^{11}$ software studies, ${ }^{12}$ and platform studies. ${ }^{13}$ Given this updated concept of media and technology, limiting these subjects as a means to convey linguistic meanings is unnecessary because they can connect people to the world without linguistic meanings.

However, these debates primarily arose in the Western context, except for some works in anthropology. The crisis of the Judeo-Christian notion of humanity has been considered to arrive along with the dehumanization of technology in the late $20^{\text {th }}$ century. However, in Japan, which had never been Judeo-Christianized, beyond-humanism phenomena were found almost everywhere even before the late $20^{\text {th }}$ century. Regardless, Japanese people noticed them in their ordinary lives. It is true that through the process of modernization after the late $19^{\text {th }}$ century, Japan introduced the Judeo-Christian notion of humanity and, at least institutionally, became a modern nation-state. However, this does not mean that people in the archipelago incorporated the modern ontological division of mind and body or nature and culture. Rather, modern technology that came from the West was networked in an ontology wherein nature was not differentiated from culture.

Without having to wait for the announcement of "God is dead" by Friedrich Nietzsche,${ }^{14}$ the Judeo-Christian God was absent in Japan. Humanity in the Judeo-Christian sense never ontologically existed, and the boundary between humans and non-humans has been ambiguous there. Furthermore, the absence of the Judeo-Christian God is not only seen in Japan but also in other Asian countries, Anglo and Latin Americas in the pre-Columbian era and Africa as well as, historically, in North and Central Europe in the pre-baptized era and even in ancient Rome before the establishment of the official Christian church. However, Roman paganism disappeared a long time ago; North and Central Europe were Christianized at least until the $10^{\text {th }}$ century; Anglo and Latin Americas were Christianized after the $15^{\text {th }}$ century, and; indigenous beliefs in Africa and South/South East Asia were backgrounded due to the Western

L. Bryant, N. Srnicek, G. Harman (eds.), The Speculative Turn: Continental Materialism and Realism, Melbourne: Re.Press, 2011.

7 R. Braidotti, Nomadic Subjects: Embodiments and Sexual Difference in Contemporary Feminist Theory, $2^{\text {nd }}$ ed., New York: Columbia University Press, 2011.

8 D. Haraway, When Species Meet, Minneapolis, MN: University of Minnesota Press, 2008.

9 P.T. Clough, J. Halley (eds.), The Affective Turn: Theorizing the Social, Durham, NC: Duke University Press, 2007.

10 J. Parikka, What Is Media Archaeology?, Cambridge: Polity Press, 2012.

11 M. Fuller, Media Ecologies: Materialist Energies in Art and Technoculture, Cambridge, MA: MIT Press, 2007.

12 M. Fuller (ed.), Software Studies: A Lexicon, Cambridge, MA: MIT Press, 2008.

13 N. Monfort, I. Bogost, Racing the Beam: The Atari Video Computer System, Cambridge, MA: MIT Press, 2009.

14 F. Nietzsche, The Gay Science, transl. by T. Common, Mineola, NY: Dover, 2006 (1882), p. 90. 
Imperialism after the $17^{\text {th }}$ century. If Western philosophers in the modern age want to find good examples of pure beyond-humanism phenomena in their own philosophical tradition, they need to go back to over 2,000 years ago. ${ }^{15}$

Contrarily, Japan has been located outside of the occupation by Western imperialism although Japan itself imitated Western imperialism before WWII and colonized Asian countries. Modern technology was implanted into the country without Judeo-Christianization after the late $19^{\text {th }}$ century. Consequently, modern technology was networked into an ontology wherein nature is not differentiated from culture. After the 1990s, debates on beyond-human phenomena emerged in the West along with the idea of technology undermining the traditional notion of humanity. For instance, Donna Haraway's notion of "natureculture" means that nature and culture cannot be separated. ${ }^{16}$ However, even before the late $20^{\text {th }}$ century, there were a lot of phenomena beyond the modern subject-object division in Japan. In the contemporary technological environment, this hybridity is more radicalized than in the West. Although the human-nature relation in Japan has been, sometimes, captured as a type of spiritual relationship between them, it should be redefined as a mode of existence of the human-world network, instead of mystifying it.

This paper will discuss the non-representational relationship between humans and technology, referring to the transition of the technological environment from the 1960s to the 1990s in Japan. Moreover, it shows an alternative type of humanity-centered limitation which would help to relativize the dominant Western context and, eventually, dismantle the West-non-West geopolitical differentiation in technology and media studies through focusing on the affective layer of human-technology assemblages.

\section{Revisiting the Empire of Signs}

In the late 1960s, French literary critic Roland Barthes came to Japan three times as a member of the French Cultural Envoy, stayed for about half a month or a month and visited a variety of sites across Japan. Through these journeys, he detected strange traits of Japanese culture and published Empire of Signs (1970) after returning to France. When Barthes wrote at the beginning of the book "I want to imagine" Japan as "a fictive nation" 17 which does not exist anywhere, he attempted to neutralize his "I" as a European man who represented Japan as a strange country in the Orient in the book. As Gayatri Spivak criticized in A Critique of Postcolonial Reason, however, Barthes's "I" forecloses the native informant and just plays with a colonialist's

15 E.g. T. Adorno, M. Horkheimer, The Dialectics of Enlightenment: Philosophical Fragments, transl. by E. Jephcott, Stanford, CA: Stanford University Press, 2002 (1944).

16 D. Haraway, The Companion Species Manifesto: Dogs, People, and Significant Otherness, Chicago, IL: Prickly Paradigm Press, 2003, p. 20.

17 R. Barthes, Empire of Signs, transl. by R. Howard, New York: Hill and Wang, 1983, p. 3. 
fictive images of Japan: "the subject-position of this I is historically constructed and produced so that it can become transparent at will". ${ }^{18}$

Although Spivak's criticism is accurate, the expression of Barthes's embarrassment in Empire of Signs could not be interpreted only as Japan being the Orient. Through his journeys, what upset him were the phenomena in Japan that undermined the modern Western representational system. In this respect, it can be said that the essay signals not only the limitation of the Western scholar's Orientalism to Japanese culture but also the limitation of his semiotic literary criticism in the 1960s. If Barthes experienced digital technology in the 2010s, such as huge LED displays of the Les Quatre Temps shopping mall at La Défense in Paris, he would have felt similar to how he had in Japan because the technology proliferated after his death in 1980 has undermined the modern Western representational system even in France. What did his structuralist framework overlook in Japan? This section reconsiders the relationship between humans and technology in 1960s Japan through Barthes's eyes, modifying the error of his views and rescuing his beyond-structuralist sentiments.

Barthes contrasts cities in the West with Tokyo in the chapter entitled "Center-City, Empty Center". According to him, all cities in the West reflect "Western metaphysics". Every city center is always "full" of diverse city facilities including churches, offices, banks, department stores, cafés, and promenades, which are the incarnated versions of spirituality, power, money, merchandise, and language: "to go downtown or to the center-city is to encounter the social 'truth', to participate in the plentitude of "reality"". ${ }^{19}$ In contrast, when Barthes visited the center of Tokyo and looked at the Imperial Palace surrounded by the forest, with an area that is approximately 115 hectares (280 acres), he felt "empty" there.

The city I am talking about (Tokyo) offers this precious paradox: it does possess a center, but this center is empty. The entire city turns around a site both forbidden and indifferent, a residence concealed beneath foliage, protected by moats, inhabited by an emperor who is never seen, which is to say, literally, by no one knows who. Daily, in their rapid, energetic, bullet-like trajectories, the taxis avoid this circle, whose low crest, the visible form of invisibility, hides the sacred "nothing". 20

Barthes concluded that, in contrast, the West is the empire of meanings, wherein signs are full of meanings, while Japan is the empire of signs, wherein signs are lack of or refuse meanings.

However, Barthes' structuralist frame overlooked the non-representational. It is true that the Imperial Place was not full of city facilities, except for several small buildings for the Emperor and Empress and the Imperial Household Agency. For this reason, he detected "empty" at the place. However, the palace was not empty.

18 G.Ch. Spivak, A Critique of Postcolonial Reason: Toward a History of the Vanishing Present, Cambridge, MA: Harvard University Press, 1999, p. 343.

19 R. Barthes, Empire of Signs, p. 30.

20 Ibid., pp. 30-32. 
A variety of plants and animals existed there. The reason why the forest seemed empty for Barthes was that he projected his semiotic frame on the forest. The binary opposition sign/meaning of Barthian semiotics is not applicable to these plants and animals because they are not the linguistic or the representational but the affective or non-representational.

Furthermore, the Imperial Palace is also the place where people feel a sense of the "truth" in Japanese cosmology. Throughout the year, several ritualistic ceremonies and events of Shinto are carried out by the Emperor and Empress. The most significant ceremony is for the harvest ritual (Niiname-sai) held at the Deity Venerating Hall (Shinka-den) of the Imperial Palace in November, wherein a variety of foods from the mountain and sea including rice wine (sake), fish, fruits, seaweed, and vegetables, are offered to the sacred deities. The Emperor prays for the fertility of the soil in front of the altar of the Hall. Shinto as worship of nature has no sacred scriptures or fixed dogma, differing from major world religions such as Christianity or Judaism. However, this does not in any way indicate that Shinto does not address any truth. The sense of "truth" in Shinto emerges not from meanings but from affects. Through the worship, the Emperor attempts to make connections with the sacred deities. British anthropologist Edward Tylor called such a "belief in spiritual beings" "animism" over one hundred years ago. ${ }^{21}$

However, this paper's purpose is not to redefine the features of Shinto or to situate it as a basis of "Japanese culture" in a conventional way but to convert these features into terms of media and technology studies. What Shinto illustrates is a type of ontological relationship between humans and non-humans in Japan. In current debates on the ontological turn movement in anthropology, animism is redefined as a type of ontology wherein humans have an internal continuity with non-humans, physically differentiating their bodies from non-humans. ${ }^{22}$ Shinto's magicality or spirituality stems from this internal continuity between humans and non-humans. However, Shinto is merely a phenomenon in the animist ontology where humans and non-humans are networked, rather than an absolute basis of the country's belief. The point is that the internal continuity emerges, thereby invalidating the binary opposition sign/meaning. To use French philosopher Gilbert Simondon's term, the process would be called "transduction", which is the transfer of energy from system A to system B. Transduction "denotes a process - be it physical, biological, mental or social — in which an activity gradually sets itself in motion, propagating within a given area, through the structuration of the different zones of the area over which it operates". ${ }^{23}$ It is not an interaction between system A and B. Through the process of transduction, both systems simultaneously emerge. Transduction is an ontogenetic process. The rituals in Shinto have been sometimes considered as magical or spiritual because they do not entail

21 E. Tylor, Primitive Culture, New York: Harper, 1958 (1871), p. 8.

22 Ph. Descola, Beyond Nature and Culture, Chicago, IL: University of Chicago Press, 2013, pp. 121-122.

23 G. Simondon, "The Genesis of the Individual", in: Incorporations, ed. by J. Crary, S. Kwinter, New York: Zone Books, 1992, p. 313. 
rationality and modern humanity. However, in Simondonian terms, what happens in Shinto can be captured without mystifying it. It is the process related to the energetics of the continuous. Through the ritual at the Imperial Palace, the Emperor makes an affective continuum between himself and the sacred deities.

A similar affective continuum emerges between the Emperor and the Japanese people - that is, between the inside and the outside of the Imperial Palace. When a large-scale natural disaster such as the Tōhoku Earthquake and Tsunami in 2011 occurs, the Emperor and Empress visit the afflicted area immediately. Their visit does not merely work to encourage victims but also to heal the victims' hearts through their comforting words and creating a strong affective continuum with victims, just like old European kings' magical powers which the Annales School historian Marc Bloch depicted in The Royal Touch. ${ }^{24}$ There exist more than 88,000 Shinto shrines in Japan. Japanese people have a custom of visiting shrines during the first three days of the new year. According to a statistic of the National Police Agency in Japan, for instance, 99.3 million people among the total population of 128 million people in Japan visited a shrine in $2009 .^{25}$

In line with this reinterpretation of the center in Tokyo, it could be said that the center of Tokyo was full of beyond-meanings against Barthes's analysis. However, despite Barthes's above-mentioned conclusion, he very clearly observed the human-technology relation in Japan in Empire of Signs. Even in the sentences just after detecting the empty at the center of 1960s Tokyo, he adequately depicted what happened around the empty. When he wrote, "in their rapid, energetic, bullet-like trajectories, the taxis avoid this circle", ${ }^{26}$ he obviously felt that the activity of the transportation systems in Tokyo seemed similar to an organism. In fact, in the chapter "The Station", he depicted a major station in Tokyo as that. "The station, a vast organism which houses the big trains, the urban trains, the subway, a department store, and a whole underground commerce". ${ }^{27}$ At the station in Tokyo, for him, humans seemed to become components of a huge organic complex, wherein a variety of heterogeneous agencies were connected to each other. Subsequently, Barthes wrote, "The Japanese station is crossed by a thousand functional trajectories, from the journey to the purchase, from the garment to food: a train can open onto a shoe stall". ${ }^{28}$ Surprisingly, here, the semiotic structuralist suddenly began to speak similar to a Latourian actor-network theorist.

In the chapter "Pachinko", he more clearly detected what happened between humans and technology in the peculiar megacity. Pachinko is a Japanese-style pinball

24 M. Bloch, The Royal Touch: Monarchy and Miracles in France and England, transl. by J.E. Anderson, New York: Dorset Press, 1989.

25 National Police Agency in Japan, The Report on Police Measures Related to People Who Go Out in New Year Days and Mountain Climbers during Year-end and New Year Holidays (in Japanese), 2009.

26 R. Barthes, Empire of Signs, p. 30.

27 Ibid., p. 38.

28 Ibid. 
machine. A player loads steel balls into a hole in front of the machine. By flipping a lever, the player propels a ball to the top of the machine. When the dispatched ball enters a winning hole, the machine releases additional balls, which can either be played or exchanged for rewards. Barthes found a mannerism peculiar to Japanese pachinko players, who completely differed from players of similar pinball machines in the West. "The pachinko is a collective and solitary game. The machines are set up in long rows; each player standing in front of his panel plays for himself, without looking at his neighbor, whom he nonetheless brushes with his elbow". ${ }^{29}$ For Barthes, this scene did not seem like that of a leisure center but of a factory. "The parlor is a hive, or a factory? The players seem to be working on an assembly line. The imperious meaning of the scene is that of a deliberate, absorbing labor". ${ }^{30}$

Barthes eventually used these impressions as proofs for elucidating that Japan was the "empire of signs" without meanings. When he looked at the forest at the center of Tokyo, he was unable to observe the non-representational relationship between the forest and Japanese people at all and, eventually, found the empty there. Nevertheless, in terms of different sites in Tokyo, he clearly observed the emergence of peculiar human-technology relations through an affective continuum between humans and non-humans (or technology). Barthes gave us the deepest insight on the features of such a continuum in the chapter "Animate/Inanimate" about bunraku (Japanese traditional puppet theatre). In bunraku, the principal operator without a black hood and a couple of sub-operators with black robes and hoods manipulate puppets that are one-half to two-thirds in size compared to humans. In Western theatrical arts, even though a puppet is animated by its operator, it lives "as a rigid portion of the actor from whom it has emanated". Contrarily, in bunraku, "Everything which we attribute to the total body and which is denied to our actors under cover of an organic, 'living' unity, the little man of Bunraku recuperates and expresses without any deception". 31 It "rejects the antinomy of animate/inanimate and dismisses the concept which is hidden behind all animation of matter and which is, quite simply, "the soul" ". ${ }^{32}$ Subsequently, Barthes speaks about the human-technology assemblage in bunraku using nice words: "the puppet no longer apes the creature, man is no longer a puppet in the divinity's hands, the inside no longer commands the outside". ${ }^{33}$ In this assemblage, the human/technology differentiation disappeared through a deep affective continuum between them. However, despite this depiction, Barthes eventually concluded this as "nothing" of meanings again.

In the last several pages of Production of Presence (2004), Hans Ulrich Gumbrecht referred to Japanese theatrical arts such as $n \bar{o}$ and kabuki dramas as well. In the first chapter, he wrote, while deconstruction insists on the impossibility of a stable

\footnotetext{
Ibid., p. 27.

Ibid., p. 28.

Ibid., p. 60.

Ibid.

Ibid., p. 63.
} 
structure of meaning by stressing the exteriority of the signifier, cultural studies as a non-hermeneutic field promises to describe the emergence of meaning apart from the assigned meaning, analyzing cultural phenomena and institutions. ${ }^{34} \mathrm{He}$ claimed that the non-hermeneutic field, however, does not help us to answer the question of "how (if at all) media and materialities of communication could have an impact on the meanings they were carrying. Only this question, however, would transcend the dimension of the metaphysical, because only this question would abandon the all too neat separation of materiality from meaning". ${ }^{35}$ For Gumbrecht, no and kabuki dramas seemed central examples to capture the production of presence. $N \bar{o}$ drama allows audiences to "cease to ask what these things mean because they seem just present and meaningful" and "observe how, while you ever so slowly begin to let things emerge, you become a part of them". ${ }^{36}$ What Barthes felt in bunraku is the same as what Gumbrecht felt in other types of Japanese theater. For Barthes, the "nothing" in bunraku indicated the lack of meaning. Contrarily, for Gumbrecht, it indicated a "presence" which he called "the state of being lost in focused intensity". 37

It must be noted that this state that the $n \bar{o}$ and kabuki dramas produced does not necessarily emerge only from the actors and a few things on the stage. It emerges between humans and a variety of things including technology in urban areas in Japan as well. People receive sensory signals from different materials, which Barthes observed, and reach "the state of being lost in focused intensity". Even though signs seem to lack any meaning, they are always connected to human bodies through their signaletic power. Japan is the "Empire of Signals".

\section{Reassembling the Social in the Empire of Signals}

In the 1990s, along with the development of electronic technology, what Barthes experienced in late 1960s Tokyo dramatically changed. Every station in Tokyo was equipped with automatic turnstiles. Old-style mechanical pachinko machines were replaced with computer-controlled machines. Highly technologized karaoke halls emerged and spread across the country. The most significant difference between the 1960s and 1990s is that the connecting interfaces between humans and technology were electrified. In the period when Barthes visited Japan, even though humans were deeply connected to technology, the connecting interfaces between them were static material surfaces of industrial products such as the concrete stairs of stations, the steel doors of trains, or the wooden arms of bunraku puppets. Therefore, his metaphor of a factory was fitted to a pachinko hall. Sounds and lights were merely

34 H.U. Gumbrecht, Production of Presence: What Meaning Cannot Convey, Stanford, CA: Stanford University Press, 2004, p. 13.

35 Ibid., p. 16.

36 Ibid., p. 151.

37 Ibid., p. 104. 
by-products yielded from the operation of pachinko machines. However, the development of electronic technology in the 1990s made it possible to control audio-visual sensory signals at a more detailed level. The connecting interfaces between humans and technology moved from mechanical surfaces to electronic ones. Consequently, body-machine relations were refigured as brain-electronics relations, in which the sense of the animistic truth emerged. Creating an internal continuity between humans and machines through sensory signals is the prominent feature across different amusement facilities or devices that proliferated in the 1990s Japan.

The pachinko machines that Barthes witnessed in the 1960s transformed into electronic gambling machines (EGM) in the 1990s. The first pachinko machine model which incorporates a probability fluctuation system and an LCD monitor, called digital pachinko (Deji-pachi), was released in the early 1990s. The probability fluctuation is the system that the probability of the next jackpot increases when a big hit takes place under certain conditions. In that period, numerous pachinko halls newly opened not only in the central districts of big cities but also around many railway stations. Unlike the major casino cities in North America and Europe, pachinko halls and machines were generally regarded as amusement facilities and machines, not as gambling facilities. Business persons or college students visited pachinko halls frequently. Consequently, the addiction to pachinko gambling became a serious social problem in the 1990s.

Due to the development of electronic technology, the level of noise emanating from pachinko machines increased in the 1990s. However, there was no rule for the same until 2012 when the Japan Pachinko Manufacturers' Association (Nihon Yugiki Kögyō Kumiai), the industry group consisting of major manufacturers of pachinko machines, added a new clause to their internal rule which defined that the factory-installed volume of pachinko machines should be $85 \mathrm{~dB}$ or less and the volume at the maximum output is $95 \mathrm{~dB}$ or less, except for alarm sounds. $90 \mathrm{~dB}$ is comparable to the sound in a noisy factory, $100 \mathrm{~dB}$ is comparable to the sound under an elevated railway when the train passes. The establishment of self-regulation on volume by the industry group indicates that even for ordinary players, the sound of pachinko machines and halls became unacceptable.

Technological sensory signals were also widely utilized in karaoke halls in the 1990s. Karaoke, a form of Japanese entertainment where amateur singers sing popular music, spread across the world in the later 1980s. Karaoke has become popular even in the Anglophone countries these days. The word karaoke is a hybrid of two Japanese words: kara (empty) and oke (orchestra). That is, it originally means to sing without an orchestra, only using a microphone. The word karaoke itself includes an implication that music machines accompanying singers are substituted for musicians in the first place. Karaoke as a form of entertainment developed in the 1970s. At that time, singers used a very basic machine similar to a small jukebox with a microphone. However, from the 1980s and throughout the 1990s, karaoke machines dramatically developed as electronic audio-visual machines and were incorporated into small 
soundproof chambers designated for singing, called karaoke boxes. The laserdisc (LD) karaoke system for business released by Pioneer Electronics in 1982 was the first machine that demarcated the era of the technologization of karaoke machines. Previously, people simply looked at song lyrics for cards and listened to music from a tape recorder. After the invention of the machine, people can sing watching the monitor that displays song lyrics and background images in accordance with the flow of music.

Parallel to that, a karaoke hall itself became a huge human-technology network including human-machine assemblages as karaoke box chambers. Autochanger $\mathrm{ka}$ raoke machines were released in 1984, which can automatically replace LDs, making it possible to seamlessly switch from one song to another song. From the late 1980s, a song that a customer chose was distributed to each box chamber from the computer in the central control room at a karaoke hall, which is connected to LD autochangers. In the 1990s, the MIDI sequence information for music data system reduced the amount of data. Consequently, a large number of songs were saved in the central control room, and songs were quickly distributed to each box chamber by a host computer. Karaoke halls, which were previously located in rural roadside areas, began to be built inside of buildings in downtown areas. In other words, indoor-type audio-visual sensory amusement spaces were scattered between restaurants, shops, and pachinko halls. The number of karaoke box chambers, which was 82,031 in 1991, doubled to 160,680 in 1996.

The normal capacity of each karaoke box chamber in Japan is less than 15 persons. Box chambers for 5 or 6 persons are the most popular. In small machine-connected-closed chambers, the affinity between colleges or classmates is fostered through an affective continuum between humans and technology. One of the prominent features of karaoke in Japan is that each attendee holds a microphone for 10 or 15 minutes. Every attendee equivalently devotes their voice to the audio-visual karaoke machine. Rather than other attendees simply listening or dancing to a single person's singing, the strength of the affinity between attendees is confirmed through the circulation of the microphone every 10 or 15 minutes, retaining an equal connection to the karaoke machine. Every attendee's devotion to technological sensory spaces is required.

\section{Disassembling the Social in the Empire of Signals}

The emergence of a large-scale human-technology network was not a new phenomenon in the 1990s. The TV broadcasting system built in 1960s Japan was the largest human-technology network in Japan for a long time. However, in parallel with the dramatic proliferation of sensory amusement facilities such as karaoke and pachinko halls throughout the 1990s in urban areas, even sensory signals of TV programs became more strong, detailed, and immediate. A typical example is that of the flashing speed of transmitted light photography (TLP) (the so-called paka-paka in Japanese), which 
is a technique of flashing a strong contrast between different color lights and which became faster from the 1990s. Although such a technique has been previously used in many animations since the 1970s, the speed of light flashing in Japanese animation became faster in the 1990s. The disappearance of the animate/inanimate, which Barthes detected in bunraku, happened at a more sensitive level in TV animation.

As W.J.T. Mitchell claimed, images intrinsically have the vital, which cannot be reduced into the semiotic. ${ }^{38}$ Additionally, Roland Barthes also found the image's resistance to meaning in his late work, especially in his exploration of photography. ${ }^{39} \mathrm{Ho}-$ wever, in his famous formulation of studium/punctum (coded/not-coded elements of the image), when punctum was defined as a "sting, speck, cut, little hole", ${ }^{40}$ Barthes looked at punctum from the perspective of the modern representational system and overlooked that the non-representational can work without such an opposition. The status of punctum against studium in his theory is similar to the status of the empire of signs against the empire of meaning. The non-representational aspect of images can even exceed the human's ability to receive sensory signals and break the human brain's representational field itself beyond merely wounding the studium. A symbolic incident occurred at 6:30 PM on December 16, 1997, in Japan, all across the country: the so-called Pokémon Shock. After watching the Pokémon TV animation, approximately 750 viewers, who were mainly children, were taken to hospitals due to photosensitive seizures. During that day's Pokémon animation, light signals from the television exceeded the limit of neuronal activity in the brain. Light signals in some scenes directly affected the children's brains. In response to this incident, TV Tokyo Corporation established the Animated Program Image Effect Production Guidelines in 1998.

Before the Pokémon Shock, a similar accident of flashing images in a TV commercial triggering seizures in people occurred in the United Kingdom in 1993. In response to this accident, a guideline to prevent seizures induced by TV broadcasting was made on request from the Independent Television Commission in the United Kingdom as well. Photosensitive seizures are not necessarily a phenomenon linked only to Japanese television broadcasting but also to the development of modern visual technology in the $20^{\text {th }}$ century. Photosensitive seizures are triggered by quick light flickers. The normal operation of neurons in the brain is excessively stimulated by external light signals and abnormal reactions of the brain are caused.

However, as Thomas Lamarre's media ecological study on the Pokémon Shock teaches us, this incident should not be reduced to neuroscience. "Neuroscientific experiments and statements are not the source or cause of this screen-brain apparatus or dispositif. They constitute key elements brought into relation through the

38 W.J.T. Mitchell, What Do Pictures Want?: The Lives and Loves of Images, Chicago, IL: University of Chicago Press, 2005, p. 6.

39 Ibid., p. 9.

40 R. Barthes, Camera Lucida: Reflections on Photography, transl. by R. Howard, New York: Hill and Wang, 1981, p. 27. 
apparatus". ${ }^{41}$ Photosensitive seizures were triggered in the onto-political field composed by the screen-brain apparatus. This apparatus is linked to different techniques such as flicker fusion, which affords a multisensory experience. Although neuroscience contributes to the analysis of the screen-brain apparatus, it does not explain the operation of this apparatus. In the respect that the onto-political field of the screen-brain apparatus is located in-between humans and the world, Lamarre found a sort of "animism" there. However, he carefully differentiated this animism from the animism discussed in anthropology with the point that the animism of transmedia ecologies is, first, related to a matter of "semblance" that something is "crossing over from platform to the character, and from the character to the user, and from the user to the platform during these interactions", and not "resemblance" in personation - the generation of persons - in which "what is matter is the person and relations among persons instead of distinctions between humans, machines, and animals" and, second, related to "the electromagnetic and signaletic". ${ }^{42}$

As previously explained, creating an internal continuity through a transductive process between humans and the world is a feature of animist ontology. Through this process, people can reach the sense of the truth of the world-needless to say, this is not the rational truth but the animistic truth. This transductive process can emerge not only between humans and natural things but also between humans and electronic technology. It is considered that the emergence of the signaletic-animistic onto-political field in the screen-brain apparatus is aided by the already-registered ontological relation between humans and the world. The sense of the truth of the world could increase in correspondence with the degree of intensity in connectivity to electronic technology. Differing from natural things, electronic technology can almost infinitely increase the degree of intensity by controlling sensory signals and the strength of connectivity. To repeat, the sense of the animistic truth emerges from forming an affective continuum between humans and the world. However, in the Pokémon Shock, the sensory signals that had an original purpose to form a deep affective continuum between humans and technology paradoxically cut off the connectivity between humans and technology.

The non-representational aspect of light signals is not separated from the representational aspect of the Pokémon animation. The story-setting of the Pokémon animation which induced photosensitive seizures was as follows. Satoshi (Ash Ketchum in the English version), Kasumi, and Takeshi visited the Pokémon center in Matcha city. In the center, usually many Pokémon are transferred. However, troubles occurred in the transfer machine. Dr. Akihabara told them that someone robbed the CG Pokémon "Polygon" Unit No. 0, entered the electronic world and did something bad. With another polygon first aircraft, the three entered the electronic world and

41 T. Lammare, The Anime Ecology: A Genealogy of Television, Animation, and Game Media, Minneapolis, MN: University of Minnesota, 2018, p. 60.

42 Ibid., pp. 354-355. 
were confronted with members of Team Rocket. The polygons fought against each other and repelled Team Rocket. However, a vaccine, which was brought from the Pokémon center to destroy a computer virus, in turn, approached the three. Although the vaccine transformed into a fighter plane and shot four missiles, Pikachu attacked these missiles by using his special technique "one million volts". In this Pikachu attack scene, strong light flickers were used to show the strength of Pikachu's supernatural power. While the Pokémon's supernatural power in this last scene was originally used to attack these missiles in this animation, audiences simultaneously felt the strength of the power through sensory signals in the animation.

To characterize Japanese popular culture including Pokémon, Anne Alison used the word "techno-animism", in which material reality comes alive. ${ }^{43}$ It must be stressed that the sense of alive in the Pokémon animation stems from sensory stimuli induced by technology as well as the representation of monsters in the TV animation. As previously stated, the representational/non-representational aspects of images work simultaneously. However, what the Pokémon Shock showed is that in the process of the realization of the animistic worldview in TV animation, the opposition of the representational/non-representational features of images was dissolved and the stability of human bodies was destroyed. To adequately represent the Pokémon's supernatural power in the animation, the non-representational had to be increased to the point where the audience's bodies could fully feel the sense of the animistic truth by retaining a strong connection with the animation. However, the disconnection happened suddenly. This does not merely indicate that the sense of the animistic truth previously related to natural things was replaced with one related to sensory signals produced by technology but also that it became difficult to retain a human-world stable relation to feel such a sense in the techno-ecology.

\section{Conclusion: Post-industrial Animistic Affect}

As the rituals at the Imperial Palace clearly indicated, the sense of the truth in animist ontology emerges from the affective continuum between humans and natural things or supernatural beings. This relationship has been depicted by using slightly ambiguous terms such as the spiritual or the magical. However, as recent debates on new animism in anthropology teach us, human-nature animistic relations would be captured as the Simondonian transductive process. ${ }^{44}$ This understanding, on the one hand, opens a way to broaden the notion of animism from human-nature relations towards human-technology relations. On the other hand, it releases understandings of human-technology relations from the exchange of socio-cultural meanings. What

43 A. Alison, Millennial Monsters: Japanese Toys and the Global Imagination, Berkeley-Los Angeles, CA: University of California Press, 2006, p. 13.

44 E. Viveiros de Castro, "Perspectival Anthropology and the Method of Controlled Evocation", Tipiti 2004, no. 2 (1), p. 18. 
happened in a variety of sensory amusement facilities and devices that proliferated in 1990s Japan was the absorption to non-representational signals to reassemble the social. Through such an electronic techno-ecology without nature in urban areas, an affective continuum between humans and technology was created. Although this techno-ecology would be captured as "empty" by Barthes, it was always full of sensory signals produced by technology.

However, this paper did not intend to reinterpret the "empire of signs" as the "empire of signals" and compare "Japanese culture" with "Western culture". This is not because such a comparison reproduces a new type of Orientalism but because the notion of "culture" itself posits a common representational field wherein different cultures are compared and overlook the non-representational in human-technology relations. Likewise, the names of "Japan" and "the West" have a danger of confining the non-representational in a geographical imagination. The non-representational in human-technology relations neither need the label of "culture" nor "Japan". Instead, it indicates a particular mode of the human-world relation. The differences between the empire of meanings and the empire of signals are not the cultural or geopolitical but rather in the modes of the human-world relation. Given the development of digital technology in the $21^{\text {st }}$ century, such differences become more complicated because the "empire of meanings" is also exposed to a flood of sensory signals of digital devices, which dramatically undermine or transform the traditional notion of humanity in Judeo-Christianity. The Barthian opposition of the representational/non-representational is dissolving. The human-world relation is becoming unstable. The West will become another "empire of signals" in which Roland Barthes will find "empty".

\section{Bibliography}

Adorno T., Horkheimer M., The Dialectics of Enlightenment: Philosophical Fragments, transl. by E. Jephcott, Stanford, CA: Stanford University Press, 2002 (1944).

Allison A., Millennial Monsters: Japanese Toys and the Global Imagination, Berkeley-Los Angeles, CA: University of California Press, 2006.

Barthes R., Empire of Signs, transl. by R. Howard, New York: Hill and Wang, 1983.

Barthes R., Camera Lucida: Reflections on Photography, transl. by R. Howard, New York: Hill and Wang, 1981.

Bloch M., The Royal Touch: Monarchy and Miracles in France and England, transl. by J.E. Anderson, New York: Dorset Press, 1989.

Braidotti R., Nomadic Subjects: Embodiments and Sexual Difference in Contemporary Feminist Theory, $2^{\text {nd }}$ ed., New York: Columbia University Press, 2011.

Bryant L., Srnicek N., Harman G. (eds.), The Speculative Turn: Continental Materialism and Realism, Melbourne: Re.Press, 2011.

Clough P.T., Halley J. (eds.), The Affective Turn: Theorizing the Social, Durham, NC: Duke University Press, 2007.

Coole D.H., Frost S. (eds.), New Materialisms: Ontology, Agency, and Politics, Durham, NC: Duke University Press, 2010. 
Descola Ph., Beyond Nature and Culture, transl. J. Lloyd, Chicago, IL: University of Chicago Press, 2013.

Fuller M., Media Ecologies: Materialist Energies in Art and Technoculture, Cambridge, MA: MIT Press, 2007.

Fuller M. (ed.), Software Studies: A Lexicon, Cambridge, MA: MIT Press, 2008.

Grusin R. (ed.), The Nonhuman Turn, Minneapolis, MN: University of Minnesota Press, 2015.

Gumbrecht H.U., Production of Presence: What Meaning Cannot Convey, Stanford, CA: Stanford University Press, 2004.

Haraway D., The Companion Species Manifesto: Dogs, People, and Significant Otherness, Chicago, IL: Prickly Paradigm Press, 2003.

Haraway D., When Species Meet, Minneapolis, MN: University of Minnesota Press, 2008.

Holbraad M., Pedersen M.A., The Ontological Turn: An Anthropological Exposition, Cambridge: Cambridge University Press, 2017.

Lamarre T., The Anime Ecology: A Genealogy of Television, Animation, and Game Media, Minneapolis, MN: University of Minnesota, 2018.

Latour B., Reassembling the Social: An Introduction to Actor-Network-Theory, Oxford: Oxford University Press, 2007.

Mitchell W.J.T., What Do Pictures Want?: The Lives and Loves of Images, Chicago, IL: University of Chicago Press, 2005.

Montfort N., Bogost I., Racing the Beam: The Atari Video Computer System, Cambridge, MA: MIT Press, 2009.

National Police Agency in Japan, The Report on Police Measures Related to People Who Go Out in New Year Days and Mountain Climbers during Year-end and New Year Holidays (in Japanese), 2009.

Nietzsche F., The Gay Science, transl. by T. Common, Mineola, NY: Dover, 2006 (1882).

Parikka J., What Is Media Archaeology?, Cambridge: Polity Press, 2012.

Simondon G., "The Genesis of the Individual”, in: Incorporations, ed. by J. Crary, S. Kwinter, New York: Zone Books, 1992, pp. 297-319.

Spivak G.Ch., A Critique of Postcolonial Reason: Toward a History of the Vanishing Present, Cambridge, MA: Harvard University Press, 1999.

Thrift N., Non-Representational Theory: Space, Politics, Affect, London: Routledge, 2007.

Tylor E., Primitive Culture, New York: Harper, 1958 (1871).

Viveiros de Castro E., "Perspectival Anthropology and the Method of Controlled Evocation", Tipiti 2004, no. 2 (1), pp. 3-22. 